Kamilla Kurczewska

\title{
Ocena zgodności z Konstytucją poselskiego projektu ustawy o jawności przychodów kościołów i związków wyznaniowych oraz zniesieniu ich przywilejów finansowych $^{1}$
}

\author{
Assessment of compliance with the Constitution of the Republic of Poland \\ of the Deputies' Bill on the Transparency of Revenues of Churches \\ and Religious Associations and the Abolition of Their Financial Privileges
}

\begin{abstract}
In the opinion of the author, the provision of the Bill, which introduces an obligation to record and disclose all benefits for churches and religious associations by units of the public finance sector, is compliant with the Constitution. However, the introduction of provisions on the rights of churches and religious associations without observing the consensual procedure provided for in the Constitution may become the basis for an effective allegation of non-compliance with the Constitution, and - in the case of relations with the Catholic Church - also of non-compliance with provisions of a ratified international agreement.
\end{abstract}

Keywords: Catholic Church, church, religious association, transparency, public finances, Constitution, concordat

Zdaniem autorki przepis projektu ustawy, wprowadzający obowiązek ewidencjonowania i ujawniania przez jednostki sektora finansów publicznych wszystkich przysporzeń dokonywanych na rzecz kościołów i związków wyznaniowych, jest zgodny z Konstytucją. Natomiast wprowadzenie zmian przepisów dotyczących uprawnień kościołów i związków wyznaniowych bez zachowania trybu konsensualnego przewidzianego w Konstytucji może stać się podstawą postawienia skutecznego zarzutu niezgodności z ustawą zasadniczą, oraz - w przypadku stosunków z Kościołem katolickim - również zarzutu nierespektowania przepisów ratyfikowanej umowy międzynarodowej.

Słowa kluczowe: Kościół katolicki, kościół, związek wyznaniowy, jawność, finanse publiczne, Konstytucja, konkordat

Doktor nauk prawnych, magister filozofii, ekspert ds. systemu gospodarczego Biura Analiz Sejmowych -

Kancelaria Sejmu, Biuro Analiz Sejmowych, Wydział Analiz Społecznych i Ekonomicznych, Zespół Oceny Regulacji Prawnych, WARSZAWA, POLSKA •

kamilla.kurczewska@sejm.gov.pl • https://orcid.org/0000-0001-9088-1419

$1 \quad$ Opinia prawna $w$ sprawie zgodności $z$ Konstytucja RP poselskiego projektu ustawy o jawności przychodów kościołów i związków wyznaniowych oraz zniesieniu ich przywilejów finansowych sporządzona 24 września 2020 r. na zlecenie Szefa Kancelarii Sejmu; BAS-WASiE-1853/20. 


\section{Przedmiot opinii}

Opinia stanowi odpowiedź na pytanie dotyczące zgodności projektu ustawy z Konstytucją RP z 2 kwietnia 1997 r. Projekt ustawy zawiera rozwiązania zapewniające transparentność przysporzeń dokonywanych na rzecz kościołów i związków wyznaniowych (dalej: KiZW) przez jednostki sektora finansów publicznych (dalej: JSFP), jawność przychodów KiZW oraz likwiduje niektóre uprawnienia KiZW.

\section{Wnioski opinii}

- Przepis projektu ustawy wprowadzający obowiązek ewidencjonowania wszystkich przysporzeń dokonywanych na rzecz kościołów i związków wyznaniowych przez jednostki sektora finansów publicznych i ujawniania ich w Biuletynach Informacji Publicznej tych jednostek jest zgodny z Konstytucją.

- Wprowadzenie w projekcie przepisów nakazujących ewidencjonowanie i ujawnianie wszystkich przychodów KiZW organom Krajowej Administracji Skarbowej oraz przepisów likwidujących uprawnienia KiZW bez zachowania trybu konsensualnego, przewidzianego w art. 25 ust. 4 i 5 Konstytucji, może stać się podstawą postawienia skutecznego zarzutu niezgodności z Konstytucją, oraz, w przypadku stosunków z Kościołem katolickim, również zarzutu nierespektowania przepisów umowy międzynarodowej (tj. art. 27 i 28 jak również art. 22 ust. 2 konkordatu), hierarchicznie wyższej niż ustawa (zgodnie $\mathrm{z}$ art. 91 ust. 2 Konstytucji).

- Wprowadzenie do projektu przepisów likwidujących prawo osób fizycznych i prawnych do zmniejszenia kwoty podatku dochodowego przez odliczenie od dochodu kwoty darowizn przekazanych na cele kultu religijnego można rozpatrywać jako zawężanie uprawnień wbrew sugestiom wynikającym z konstytucyjnej zasady pomocniczości nakazującej umacniać uprawnienia obywateli i ich wspólnot (preambuła, wiersz 19 Konstytucji).

- Wprowadzenie do projektu przepisów likwidujących możliwość dotowania i subwencjonowania KiZW przez jednostki samorządu terytorialnego oraz dokonywania przysporzeń majątkowych pod tytułem darowizny KiZW przez spółki prawa handlowego z udziałem Skarbu Państwa, państwowych jednostek organizacyjnych lub jednostek samorządu terytorialnego należy ocenić w kontekście zgodności z konstytucyjną zasadą równości. Takie wykluczające sformułowanie przepisu - bez wskazania kryteriów innych niż „rodzaj podmiotu” - jest podstawą do postawienia zarzutu naruszenia art. 32 ust. 1 Konstytucji.

- Okoliczność w postaci przypuszczenia, że KiZW otrzymały równowartość przejętych przez państwo „nieruchomości ziemskich związków wyznaniowych”, po jej zweryfikowaniu, jest, w przypadku Kościoła katolickiego, podstawą do 
stwierdzenia potrzeby „koniecznych zmian” ustawodawstwa polskiego i uruchomienia trybu, o którym mówi art. 22. ust. 2 konkordatu.

- Wskazana jest kompleksowa ocena zgodności całościowych ram normatywnych działalności służącej celom humanitarnym, charytatywno-opiekuńczym, naukowym i oświatowo-wychowawczym, prowadzonej przez instytucje państwowe $\mathrm{z}$ ramami normatywnymi prowadzenia takiej działalności przez kościelne osoby prawne Kościoła katolickiego - w kontekście art. 22 ust. 1 konkordatu "zrównującego" tę działalność „pod względem prawnym”, tj. pod względem uprawnień i obowiązków oraz ewentualne uruchomienie specjalnego trybu, $\mathrm{w}$ celu uzgodnienia zmian uznanych za konieczne.

\section{Uzasadnienie}

1. Artykuł 5 projektu ustawy wprowadzający obowiązek ewidencjonowania (informowania) i ujawniania wszystkich przysporzeń dokonywanych na rzecz KiZW przez JSFP jest rozwiązaniem operacjonalizującym konstytucyjne prawo obywatela do informacji o działalności organów władzy publicznej, wynikające wprost $\mathrm{z}$ art. 61 ust. 1 zdanie pierwsze Konstytucji ${ }^{2}$, co oznacza zgodność tego przepisu $\mathrm{z}$ ustawą zasadniczą.

Wprowadzenie obowiązku ewidencjonowania i ujawniania wszystkich przysporzeń dokonywanych na rzecz KiZW przez państwowe osoby prawne oraz spółki prawa handlowego, w których Skarb Państwa, podmioty sektora finansów publicznych lub państwowe osoby prawne posiadają przynajmniej 30\% udziałów albo akcji, należy oceniać w kontekście brzmienia art. 61 ust. 1 zdanie drugie Konstytu$\mathrm{cji}^{3}$. Podkreślenia wymaga fakt, że interpretacja projektowanego przepisu zgodna $\mathrm{z}$ art. 61 ust. 1 zdanie drugie Konstytucji, ograniczy obowiązek ujawnienia tylko do tych przysporzeń, które mają związek z gospodarowaniem mieniem komunalnym lub majątkiem Skarbu Państwa i wykonywaniem zadań władzy publicznej.

2. Projektowane przepisy:

- wprowadzające obowiązek ewidencjonowania przychodów przez jednostki organizacyjne kościołów, związków wyznaniowych oraz inne kościelne osoby prawne, informowania o nich naczelników urzędów skarbowych oraz publikowania zbiorczych informacji o tych przychodach w Biuletynie Informacji Publicznej przez Szefa Krajowej Administracji Skarbowej (art. 4 projektu),

2 „Obywatel ma prawo do uzyskiwania informacji o działalności organów władzy publicznej oraz osób pełniących funkcje publiczne”.

3 „Prawo to [do informacji, przyp. K.K.] obejmuje również uzyskiwanie informacji o działalności organów samorządu gospodarczego i zawodowego, a także innych osób oraz jednostek organizacyjnych w zakresie, w jakim wykonują one zadania władzy publicznej i gospodarują mieniem komunalnym lub majątkiem Skarbu Państwa”. 
- likwidujące Fundusz Kościelny (art. 14 projektu),

- likwidujące opłacanie składek na ubezpieczenie emerytalne, rentowe i wypadkowe duchownych, członków zakonów kontemplacyjnych klauzurowych, misjonarzy w okresach pracy na terenach misyjnych przez Fundusz Kościelny (art. 31 projektu),

- likwidujące opłacanie składek na ubezpieczenie zdrowotne duchownych oraz alumnów wyższych seminariów duchownych i teologicznych, postulantów, nowicjuszy i juniorystów oraz ich odpowiedników, z wyłączeniem osób duchownych będących podatnikami podatku dochodowego od osób fizycznych lub zryczałtowanego podatku dochodowego od przychodów osób duchownych, przez Fundusz Kościelny, dotowany przez budżet państwa w tym zakresie (art. 33 projektu),

- likwidujące prawo realizacji inwestycji kościelnych, nie służących bezpośrednio celom sakralnym (art. 16, 17, 20, 21, 23, 24, 25, 27, 28, 29 projektu),

- likwidujące zwolnienie podatkowe - w odniesieniu do podatku od nieruchomości od nieruchomości używanej do celów niemieszkalnych z wyjątkiem części zajmowanej na wykonywanie działalności gospodarczej (art. 15, 16, 17, $20,21,22,23,24,25,26,27,28,29$ projektu),

- ograniczające zwolnienie z podatku dochodowego dochodów z działalności gospodarczej osób prawnych kościołów i związków wyznaniowych do dochodów przeznaczonych - w przypadku inwestycji - na inwestycje, których wyłącznym przedmiotem są punkty katechetyczne i zakłady charytatywno-opiekuńcze oraz remonty tych obiektów ${ }^{4}$ (art. 15, 16, 17 projektu) ${ }^{5}$,

$4 \quad \mathrm{~W}$ obecnym stanie prawnym zwolnienie z podatku dochodowego obejmuje - obok dochodów przeznaczonych na cele kultowe, oświatowo-wychowawcze, naukowe, kulturalne, działalność charytatywno-opiekuńczą, punkty katechetyczne, konserwację zabytków - również dochody przeznaczone na inwestycje sakralne i inwestycje kościelne, których przedmiotem są punkty katechetyczne i zakłady charytatywno-opiekuńcze, jak również remonty tych obiektów (por. art. 13 ust. 5 ustawy o gwarancjach wolności sumienia i wyznania, art. 55 ust. 3 ustawy o stosunku Państwa do Kościoła Katolickiego w Rzeczypospolitej Polskiej oraz art. 40 ust. 3 ustawy o stosunku Państwa do Polskiego Autokefalicznego Kościoła Prawosławnego). Projekt zachowuje pozostałe warunki zwolnienia z podatku.

5 Projektowana ustawa uchyla również art. 55 ust. 2 ustawy o stosunku Państwa do Kościoła Katolickiego w Rzeczypospolitej Polskiej oraz art. 40 ust. 2 ustawy o stosunku Państwa do Polskiego Autokefalicznego Kościoła Prawosławnego, które zwalniają kościelne osoby prawne od opodatkowania z tytułu przychodów z ich działalności niegospodarczej oraz z obowiązku prowadzenia w tym zakresie dokumentacji wymaganej przez przepisy o zobowiązaniach podatkowych. W mocy pozostaje jednak przepis ogólny dotyczący tych zwolnień zawarty w art. 13 ust. 2 ustawy o gwarancjach wolności sumienia i wyznania, stosowany do wszystkich kościołów i związków wyznaniowych (zob. też art. 3 ust. 2 ustawy o stosunku Państwa do Kościoła Katolickiego w Rzeczypospolitej Polskiej i art. 3 ust. 2 ustawy o stosunku Państwa do Polskiego 
- likwidujące uprawnienie do nieodpłatnego nabywania własności przez osoby prawne Kościoła katolickiego (które po dniu 8 maja 1945 r. podjęły działalność na tzw. ziemiach zachodnich i północnych) gruntów znajdujących się w zasobach Państwowego Funduszu Ziemi albo w Zasobie Własności Rolnej Skarbu Państwa (art. 16 projektu),

- likwidujące uprawnienie nabycia w drodze bezprzetargowej w sytuacji zbycia nieruchomości kościołom i związkom wyznaniowym na cele działalności sakralnej (art. 30 projektu),

- likwidujące uprawnienie do otrzymania bonifikaty od ceny sprzedaży nieruchomości w drodze bezprzetargowej, w sytuacji sprzedaży nieruchomości kościołom i związkom wyznaniowym na cele działalności sakralnej (art. 30 projektu),

- likwidujące ochronę przed prawem pierwokupu Skarbu Państwa w obrocie nieruchomościami między kościelnymi osobami prawnymi Kościoła katolickiego (art. 16 projektu),

- likwidujące ochronę przed prawem pierwokupu gminy w sytuacji sprzedaży nieruchomości lub prawa użytkowania wieczystego następującego między osobami prawnymi tego samego kościoła lub związku wyznaniowego (art. 30),

- likwidujące uprawnienie do nabycia nieruchomości rolnej przez osoby prawne działające na podstawie przepisów o stosunku państwa do Kościoła katolickiego w Rzeczypospolitej Polskiej, o stosunku państwa do innych kościołów i związków wyznaniowych oraz o gwarancjach wolności sumienia i wyznania (art. 32),

- likwidujące ochronę przed prawem wykupu przez Krajowy Ośrodek działający na rzecz Skarbu Państwa w sytuacji, gdy przeniesienie własności nieruchomości rolnej następuje między osobami prawnymi tego samego kościoła lub związku wyznaniowego (art. 32),

- likwidujące ochronę przed prawem dzierżawcy do pierwokupu dzierżawionej nieruchomości rolnej w sytuacji sprzedaży tej nieruchomości pomiędzy osobami prawnymi tego samego kościoła lub związku wyznaniowego (art. 32). należy ocenić szczególnie w kontekście:

- $\quad$ art. 25 ust. 4 i ust. 5 Konstytucji formułującego układowy model trybu regulacji stosunków między Rzecząpospolitą Polską a Kościołem katolickim oraz innymi kościołami i związkami wyznaniowymi ${ }^{6}$,

Autokefalicznego Kościoła Prawosławnego), który projektodawcy zachowują w niezmienionym brzmieniu (zob. art. 15 pkt 2 projektu nadający nowe brzmienie ust. 5 i uchylający ust. 6). Skutki wskazanego pominięcia w postaci bezskuteczności działań projektodawcy są omówione w OSR analizowanej ustawy w pkt V (1419-20).

6 Ust. 4. „Stosunki między Rzecząpospolitą Polską a Kościołem Katolickim określają umowa międzynarodowa zawarta ze Stolicą Apostolską i ustawy”; ust. 5. „Stosunki między Rzecząpospolitą Polską a innymi kościołami oraz związkami wyznaniowymi 
- $\quad$ art. 25 ust. 1 Konstytucji formułującego zasadę równouprawnienia $\mathrm{KiZW}^{7}$,

- w przypadku Kościoła katolickiego - art. 91 ust. 2 Konstytucji ${ }^{8}$ formułującego zasadę pierwszeństwa umowy międzynarodowej ratyfikowanej za uprzednią zgodą wyrażoną w ustawie przed ustawą oraz w kontekście art. 22 ust. 2, 27 i 28 konkordatu9 , zawierających postanowienia o: powoływaniu komisji, regulacji nowych lub dodatkowych rozwiązań w drodze nowych umów oraz o usuwaniu różnic dotyczących interpretacji lub stosowania konkordatu na drodze dyplomatycznej.

Wymienione wyżej przepisy wskazują bezspornie na konsensualny tryb kształtowania stosunków między państwem a KiZW (art. 25 ust. 4 i 5 Konstytucji oraz w przypadku Kościoła katolickiego - również art. 22 ust. 2 oraz art. 27 i 28 konkordatu), natomiast różnie wyznaczany jest zakres spraw wymagający użycia tego trybu ze względu na przyjmowanie szerokiego lub zawężanego rozumienia pojęć „stosunków”, „autonomii”, „niezależności”, „nowych”, „dodatkowych”. Rozumienie pojęcia „stosunki” jako obejmujące swym zakresem kwestie finansowania i wymagające zastosowania trybu układowego przyjmują: D. Walencik ${ }^{10}$, M. Zawiślak ${ }^{11}$, P. Stanisz ${ }^{12}$,

określają ustawy uchwalone na podstawie umów zawartych przez Radę Ministrów z ich właściwymi przedstawicielami”.

7 „Kościoły i inne związki wyznaniowe są równouprawnione”.

8 „Umowa międzynarodowa ratyfikowana za uprzednią zgodą wyrażoną w ustawie ma pierwszeństwo przed ustawą, jeżeli ustawy tej nie da się pogodzić z umową".

9 Konkordat między Stolicą Apostolską i Rzecząpospolitą Polską, podpisany w Warszawie 28 lipca 1993 r., Dz.U. 1998, nr 51, poz. 318. Art. 27. „Sprawy wymagające nowych lub dodatkowych rozwiązań będą regulowane na drodze nowych umów między Układającymi się Stronami albo uzgodnień między Rządem Rzeczypospolitej Polskiej i Konferencją Episkopatu Polski upoważnioną do tego przez Stolicę Apostolską"; art. 28. „Układające się Strony będą usuwać na drodze dyplomatycznej zachodzące między nimi różnice dotyczące interpretacji lub stosowania niniejszego Konkordatu”. D. Walencik, Konkordat a sfera finansowo-majątkowa Kościoła Katolickiego w Polsce [w:] Konkordat Polski, red. P. Borecki, C. Janik, M. Winiarczyk-Kossakowska, Warszawa 1993, s. 150, oraz D. Walencik, Finansowanie Kościoła Katolickiego w Polsce [w:] Konkordat: ocena z perspektywy 15 lat obowiązywania w Polsce w świetle art. 22 i 27 konkordatu oraz prac komisji konkordatowych - perspektywa zmian, red. P. Kroczek, seria „Annales Cannonici. Monographiae”, Kraków 2014, s. 64, i inne publikacje tego autora.

11 M. Zawiślak, Zmiana systemu finansowania Kościoła Katolickiego w świetle Konstytucji RP i Konkordatu [w:] Układowe formy regulacji stosunków między państwem a związkami wyznaniowymi (art. 25 ust. 4-5 Konstytucji RP), red. P. Stanisz, M. Ordon, Lublin 2013, s. 417-418.

12 P. Stanisz, Perspektywy zmiany systemu finansowania kościołów i innych związków wyznaniowych $w$ Polsce, "Studia z Prawa Wyznaniowego” 2009, t. 12, s. 14, oraz P. Stanisz, Naczelne zasady instytucjonalnych relacji Państwo-Kościół [w:] A. Mezglewski, H. Misztal, P. Stanisz, Prawo wyznaniowe, Warszawa 2008, s. 70-71. 
J. Krukowski ${ }^{13}$, P. Sobczyk ${ }^{14}$, P. Czarny ${ }^{15}$, P. Chybalski ${ }^{16}$, J. Lipski ${ }^{17}$. Pogląd ten jest wzmocniony brzmieniem punktu 5 oświadczenia rządowego podpisanego w Warszawie w dniu 28 lipca 1993 r., w którym Rada Ministrów deklaruje, że: „Konkordat uznaje określone ustawodawstwem polskim kompetencje organów państwowych do regulowania kwestii finansowych i podatkowych kościelnych osób prawnych i fizycznych. W tym celu strona państwowa zapozna się z opinią strony kościelnej w łonie odpowiedniej Komisji, o której mowa w artykule 22 ust. 2 i 3"18.

Odmienne rozumienie zakresu materii objętej nakazem zastosowania trybu układowego, prowadzące do wniosku, że kwestie danin na rzecz państwa oraz regulacje zaszłości majątkowych na styku państwo-związek wyznaniowy mogą być normowane bez zastosowania trybu bilateralnego, prezentują P. Borecki ${ }^{19}$

13 J. Krukowski, Konstytucyjny system relacji między państwem a Kościołem katolickim oraz innymi kościołami i zwiąkami wyznaniowymi [w:] Ustrój konstytucyjny Rzeczypospolitej Polskiej, red. R. Mojak, Lublin 2000, s. 105-106, oraz J. Krukowski, Realizacja Konkordatu z 1993 r. w polskim porzadku prawnym [w:] Konkordat polski w 10 lat po ratyfikacji, red. J. Wroceński, H. Pietrzak, Warszawa 2008, s. 128-129.

14 P. Sobczyk, Proceduralna niekonstytucyjność nowelizacji ustawy o stosunku Państwa do Kościoła Katolickiego w Rzeczypospolitej Polskiej, „Studia Politologiczne” 2012, nr 23, http://www.studiapolitologiczne.pl/pdf-117287-46482?filename=Proceduralna.pdf [dostęp: 18 września 2020 r.].

15 P. Czarny, Opinia prawna $z$ dnia 8 października 2012 r. w sprawie obowiązku zasiegania opinii co do zmian w ustawach regulujacych stosunek państwa do poszczególnych kościołów i związków wyznaniowych, „Zeszyty Prawnicze BAS” 2012, nr 4(36), s. 86.

16 P. Chybalski, Opinia prawna $z$ dnia 2 lutego 2012 r. w sprawie zakresu obowiazku przeprowadzenia konsultacji dotyczacych poselskiego projektu ustawy o zmianie ustawy o przejęciu przez Państwo dóbr martwej ręki, poręczeniu proboszczom gospodarstw rolnych i utworzeniu Funduszu Kościelnego oraz niektórych innych ustaw; BAS-WAUiP-122/12, niepubl.

17 J. Lipski, Opinia prawna na temat poselskiego projektu ustawy o zmianie ustawy o przejęciu przez Państwo dóbr martwej ręki, poręczeniu proboszczom posiadania gospodarstw rolnych i utworzeniu Funduszu Kościelnego oraz niektórych innych ustaw (druk nr 1216); BAS-WAL-841/13, niepubl.

18 Pogląd ten jest wzmocniony brzmieniem pkt 5 oświadczenia rządowego z 26 stycznia 1998 r. w sprawie deklaracji rządu Rzeczypospolitej Polskiej z 15 kwietnia 1997 r. w celu zapewnienia jasnej wykładni przepisów konkordatu między Stolicą Apostolską a Rzecząpospolitą Polską (M.P. nr 4, poz. 51). Zob. też wskazującą na art. 27 konkordatu i art. 25 ust. $5 \mathrm{w}$ odniesieniu do innych KiZW jako podstawę działań odpowiedź na interpelację nr 2238 w sprawie prac nad zmianą modelu finansowania Kościoła katolickiego z budżetu państwa. Odpowiadający: podsekretarz stanu w Ministerstwie Spraw Wewnętrznych i Administracji Sebastian Chwałek, Warszawa, 11 maja 2016 r., http://sejm.gov.pl/sejm8.nsf/InterpelacjaTresc.xsp?key=6959F9BE [dostęp: 18 września 2020 r.].

19 P. Borecki, Respektowanie polskiego konkordatu z 1993 roku. Wybrane problemy, Warszawa 2012. 
i A. Czochara ${ }^{20}$. Odnotować również należy, że w okresie obowiązywania art. 25 Konstytucji rzeczywiście uchwalano ustawy dotyczące tych zagadnień bez zastosowania trybu bilateralnego ${ }^{21}$.

Analizy sformułowań użytych w obu aktach i ich wyniki interpretacyjne obecne w literaturze, praktyce ustawodawczej oraz orzecznictwie Trybunału Konstytucyjnego prowadzą do rozbieżnych wniosków, jednakże poza wszelką wątpliwością projektowane przepisy wprowadzane jednostronnie, bez uprzednich umownych uzgodnień $\mathrm{z}$ KiZW, są narażone na skuteczny zarzut niezgodności z Konstytucją 22 .

3. Wprowadzenie do projektu przepisów likwidujących prawo osób fizycznych i prawnych do zmniejszenia kwoty podatku dochodowego przez odliczenie od dochodu kwoty darowizn przekazanych na cele kultu religijnego (art. 18 i 19 projektu) można rozpatrywać jako zawężanie uprawnień wbrew sugestiom wynikającym z konstytucyjnej zasady pomocniczości nakazującej umacniać uprawnienia obywateli i ich wspólnot (preambuła, wiersz 19 Konstytucji).

Sformułowanie projektowanego przepisu likwidującego możliwość dotowania i subwencjonowania KiZW przez jednostki samorządu terytorialnego oraz dokonywania przysporzeń majątkowych pod tytułem darowizny KiZW przez spółki prawa handlowego z udziałem Skarbu Państwa, państwowych jednostek organizacyjnych lub jednostki samorządu terytorialnego (art. 15 projektu) należy ocenić w kontekście zgodności z konstytucyjną zasadą równości (art. 32 ust. 1 Konstytucji). Z artykułu tego wynika pozytywny obowiązek ustawodawcy do podejmowania działań mających na celu możliwie najszerszą realizację za-

20 A. Czohara, Specyfika ugód i orzeczeń w postępowaniu regulacyjnym [w:] A. Czohara, T.J. Zieliński, Ustawa o stosunku Państwa do gmin wyznaniowych żydowskich $w$ Polsce. Komentarz, Warszawa 2012, s. 255-265, za: T.J. Zieliński, Implikacje art. 25 ust. 5 Konstytucji RP dla procedury parlamentarnej [w:] Układowe formy regulacji stosunków między państwem a związkami wyznaniowymi (art. 25 ust. 4-5 Konstytucji RP), red. P. Stanisz, M. Ordon, Lublin 2013, s. 318.

21 Najmocniejszym przykładem jest ustawa z 16 grudnia 2010 r. o zmianie ustawy o stosunku Państwa do Kościoła Katolickiego w Rzeczypospolitej Polskiej (Dz.U. 2011, nr 18, poz. 89) znosząca Komisję Majątkową.

22 Zob. wyrok Trybunału Konstytucyjnego z 2 kwietnia 2003 r., sygn. akt K 13/02, Dz.U. nr 62, poz. 577: „Z art. 25 Konstytucji wynika ponadto dla organów władzy publicznej obowiązek poszukiwania w sferze stosunków z kościołami i związkami wyznaniowymi rozwiązań prawodawczych o charakterze konsensualnym, które znajdują akceptację adresatów. Ustawodawca nie może zatem podejmować jednostronnych ingerencji w sferę stosunków między poszczególnymi kościołami i związkami wyznaniowymi” oraz wyrok TK z 16 kwietnia 2009 r., sygn. akt P 11/08, dotyczący oceny aspektu proceduralnego przy badaniu konstytucyjności prawa, stwierdzający niezgodność aktu ze wskazanymi przepisami Konstytucji „przez to że został uchwalony przez Sejm bez dochowania trybu wymaganego do jego wydania”. 
sady równości, w tym w odniesieniu również do podmiotów innych niż osoby fizyczne ${ }^{23}$. W mojej opinii nie można uznać za uzasadnione wykluczenie osób prawnych KiZW w stosunku do innych rodzajów osób prawnych tylko na podstawie posiadania statusu „osoby prawnej KiZW” bez odniesienia do rodzajów aktywności ${ }^{24}$. Takie wykluczające brzmienie przepisu - bez wskazania kryteriów innych niż „rodzaj podmiotu” - jest podstawą do postawienia zarzutu naruszenia konstytucyjnej zasady równości.

4. Okoliczność w postaci przypuszczenia, że KiZW otrzymały równowartość przejętych przez państwo „nieruchomości ziemskich związków wyznaniowych” ${ }^{25}$, po jej zweryfikowaniu ${ }^{26}$, jak również występowanie praktyk ocenianych jako niemających uzasadnienia $\mathrm{w}$ ratio legis wprowadzanych przepisów ${ }^{27}$, jest, w przy-

23 Komentarz do art. 32 Konstytucji Rzeczypospolitej Polskiej, red. L. Garlicki, M. Zubik, 2016, LEX, teza 19 i 23.

24 Kryteria różnicowania uzasadniające odmienne traktowanie podmiotów podobnych zob. orzeczenie TK z 3 września 1996 r., sygn. akt K 10/96, OTK 1996, nr 4, poz. 33.

25 Przejęcie na podstawie ustawy z 20 marca 1950 r. o przejęciu przez Państwo dóbr martwej ręki, poręczeniu proboszczom posiadania gospodarstw rolnych i utworzeniu Funduszu Kościelnego, Dz.U. nr 9, poz. 87.

26 Dostępne dane są niepełne i różnokontekstowe, przez co niewystarczające do formułowania adekwatnych wniosków. Sprawozdanie o stanie mienia Skarbu Państwa według stanu na dzień 31 grudnia 2018 r., s. 43, http://orka.sejm.gov.pl/Druki9ka.nsf/0/ E0AC574E0DB6F2A3C12584CF003ECFED/\%24File/72.pdf. [dostęp: 18 września 2020 r.]; wskazuje stan własności nieruchomości KiZW w jednym momencie czasowym i jest to 139416 ha, z kolei odpowiedź J. Ardanowskiego na interpelację nr 3393 w sprawie nieodpłatnego przekazania gruntów Zasobu Własności Rolnej Skarbu Państwa (ZWRSP) na rzecz kościelnych osób prawnych informuje, że od dnia 1 stycznia 1992 r. do dnia 31 grudnia 2019 r. z Zasobu Własności Rolnej Skarbu Państwa przekazano nieodpłatnie na rzecz kościelnych osób prawnych 90263 ha, http://www.sejm. gov.pl/Sejm9.nsf/interpelacja.xsp?typ=INT\&nr=3393 [dostęp: 18 września 2020 r.]. Informacje o nieruchomościach i ich obecnym gospodarczym wykorzystaniu pochodzą głównie z doniesień medialnych (np. T. Resler, A. Filak, Raport Stowarzyszenia Obywatelskich Inicjatyw Społecznych i Historycznych. Jak Trybunał Konstytucyjny usankcjonował bezterminowe uwłaszczanie Kościoła katolickiego na państwowych gruntach rolnych na tzw. Ziemiach Zachodnich i Pólnocnych, http://www.soish.pl/ wp-content/uploads/2020/01/Jak-wyrok-Trybunału-Konstytucyjnego-usankcjonował-bezterminowe-uwłaszczanie-Kościoła-katolickiego-na-państwowych-gruntach-rolnych_af.pdf [dostęp: 18 września 2020 r.]; i kolejny przykład: Mieszkanie od parafii, biuro od zakonu, „Rzeczpospolita” z 18 lipca 2020 r., https://www.rp.pl/ Mieszkaniowe/307189878-Mieszkanie-od-parafii--biuro-od-zakonu.html [dostęp: 18 września 2020 r.]. Zwraca uwagę brak scentralizowanej, kompletnej i uporządkowanej informacji pozwalającej formułować należycie uzasadnione wnioski.

27 Szczególnie art. 70a ustawy z 17 maja 1989 r. o stosunku Państwa do Kościoła Katolickiego w Rzeczypospolitej Polskiej (t.j. Dz.U. 2019, poz. 1347) „1. Osobom prawnym Kościoła Katolickiego, które po dniu 8 maja 1945 r. podjęły działalność na 
padku Kościoła katolickiego, podstawą do stwierdzenia potrzeby „koniecznych zmian" ustawodawstwa polskiego i uruchomienia trybu, o którym mówi art. 22. ust. $2^{28}$ konkordatu.

Wskazana jest również kompleksowa ocena zgodności całościowych ram normatywnych działalności służącej celom humanitarnym, charytatywno-opiekuńczym, naukowym i oświatowo-wychowawczym (dotyczących obowiązków sprawozdawczych, zwolnień i ulg podatkowych, innych uprawnień), prowadzonej przez instytucje państwowe ${ }^{29} \mathrm{z}$ ramami normatywnymi prowadzenia takiej działalności przez kościelne osoby prawne Kościoła katolickiego - w kontekście art. 22 ust. 1 konkordatu „zrównującego” tę działalność „pod względem prawnym”, tj. pod względem uprawnień i obowiązków oraz ewentualne uruchomienie specjalnego trybu ${ }^{30}$, w celu uzgodnienia koniecznych zmian $^{31}$.

\section{Bibliografia}

Borecki P., Dopuszczalna wysokość odliczeń darowizn na działalność charytatywno-opiekuńczą kościołów. Glosa do uchwały NSA z dnia 14 marca 2004 r., „Glosa” 2006, nr 2.

Borecki P., Respektowanie polskiego konkordatu z 1993 roku. Wybrane problemy, Warszawa 2012.

Chybalski P., Opinia prawna $z$ dnia 2 lutego 2012 r. w sprawie zakresu obowiązku przeprowadzenia konsultacji dotyczacych poselskiego projektu ustawy o zmianie ustawy o prze-

Ziemiach Zachodnich i Północnych, mogą być, na ich wniosek, przekazane nieodpłatnie na własność grunty znajdujące się w zasobach Państwowego Funduszu Ziemi albo w Zasobie Własności Rolnej Skarbu Państwa. Jeżeli grunty te znajdują się w zarządzie lub użytkowaniu osób prawnych, przekazanie na własność może nastąpić wyłącznie za zgodą tych osób”. Przepis ten jest nazywany obrazowo „perpetuum mobile", umożliwiając wielokrotne występowanie o przyznanie ustawowego areału i obrót otrzymanymi nieruchomościami rolnymi. C. Łazarewicz Prześwietlamy majatek Kościoła, „Polityka” z 18 marca 2018 r. https://www.polityka.pl/tygodnikpolityka/ kraj/1509032,1,przeswietlamy-majatek-kosciola.read [dostęp: 18 września 2020 r.].

„Przyjmując za punkt wyjścia w sprawach finansowych instytucji i dóbr kościelnych oraz duchowieństwa obowiązujące ustawodawstwo polskie i przepisy kościelne Układające się Strony stworzą specjalną komisję, która zajmie się koniecznymi zmianami. Nowa regulacja uwzględni potrzeby Kościoła biorąc pod uwagę jego misję oraz dotychczasową praktykę życia kościelnego w Polsce".

Zob. P. Borecki Dopuszczalna wysokość odliczeń darowizn na działalność charytatywno-opiekuńczą kościołów. Glosa do uchwały NSA z dnia 14 marca 2004 r., „Glosa” 2006, nr 2, poz. 119.

30 Zob. przypis 15

31 Wprowadzanie zmian w sytuacji KiZW innych niż Kościół katolicki wymaga stosowania trybów opiniowania przewidzianych w ustawach regulujących wzajemne stosunki tych KiZW z państwem. 
jęciu przez Państwo dóbr martwej ręki, poręczeniu proboszczom gospodarstw rolnych i utworzeniu Funduszu Kościelnego oraz niektórych innych ustaw; BAS-WAUiP-122/12, niepubl.

Czarny P., Opinia prawna z dnia 8 października 2012 r. w sprawie obowiąku zasięgania opinii co do zmian w ustawach regulujących stosunek państwa do poszczególnych kościołów i związków wyznaniowych, „Zeszyty Prawnicze BAS” 2012, nr 4(36).

Czohara A., Specyfika ugód i orzeczeń w postępowaniu regulacyjnym [w:] A. Czohara, T.J. Zieliński, Ustawa o stosunku Państwa do gmin wyznaniowych żydowskich w Polsce. Komentarz, Warszawa 2012.

Komentarz do art. 32 Konstytucji Rzeczypospolitej Polskiej, red. L. Garlicki, M. Zubik, 2016, LEX.

Krukowski J., Konstytucyjny system relacji między państwem a Kościołem katolickim oraz innymi kościołami i związkami wyznaniowymi [w:] Ustrój konstytucyjny Rzeczypospolitej Polskiej, red. R. Mojak, Lublin 2000.

Krukowski J., Realizacja Konkordatu z 1993 r.w polskim porządku prawnym [w:] Konkordat polski w 10 lat po ratyfikacji, red. J. Wroceński, H. Pietrzak, Warszawa 2008.

Lipski J., Opinia prawna na temat poselskiego projektu ustawy o zmianie ustawy o przejęciu przez Państwo dóbr martwej ręki, poręczeniu proboszczom posiadania gospodarstw rolnych i utworzeniu Funduszu Kościelnego oraz niektórych innych ustaw (druk nr 1216); BAS-WAL-841/13, niepubl.

Łazarewicz C., Prześwietlamy majątek Kościoła, „Polityka” z 18 marca 2018 r. https://www. polityka.pl/tygodnikpolityka/kraj/1509032,1,przeswietlamy-majatek-kosciola.read.

Mieszkanie od parafii, biuro od zakonu, „Rzeczpospolita” z 18 lipca 2020 r., https://www. rp.pl/Mieszkaniowe/307189878-Mieszkanie-od-parafii-biuro-od-zakonu.html.

Resler T., Filak A., Raport Stowarzyszenia Obywatelskich Inicjatyw Społecznych i Historycznych. Jak Trybunat Konstytucyjny usankcjonowat bezterminowe uwłaszczanie Kościoła katolickiego na państwowych gruntach rolnych na tzw. Ziemiach Zachodnich $i$ Północnych, http://www.soish.pl/wp-content/uploads/2020/01/Jak-wyrok-Trybunału-Konstytucyjnego-usankcjonował-bezterminowe-uwłaszczanie-Kościoła-katolickiego-na-państwowych-gruntach-rolnych_af.pdf.

Sobczyk P., Proceduralna niekonstytucyjność nowelizacji ustawy o stosunku Państwa do Kościoła Katolickiego w Rzeczypospolitej Polskiej, „Studia Politologiczne” 2012, nr 23, http://www.studiapolitologiczne.pl/pdf-117287-46482?filename=Proceduralna.pdf.

Sprawozdanie o stanie mienia Skarbu Państwa według stanu na dzień 31 grudnia 2018 r., http://orka.sejm.gov.pl/Druki9ka.nsf/0/E0AC574E0DB6F2A3C12584CF003ECFED/ \%24File/72.pdf.

Stanisz P., Perspektywy zmiany systemu finansowania kościołów i innych związków wyznaniowych $w$ Polsce, „Studia z Prawa Wyznaniowego” 2009, t. 12.

Stanisz P., Naczelne zasady instytucjonalnych relacji Państwo-Kościół [w:] A. Mezglewski, H. Misztal, P. Stanisz, Prawo wyznaniowe, Warszawa 2008.

Walencik D., Finansowanie Kościoła Katolickiego w Polsce [w:] Konkordat: ocena z perspektywy 15 lat obowiązywania $w$ Polsce $w$ świetle art. 22 i 27 konkordatu oraz prac 
komisji konkordatowych - perspektywa zmian, red. P. Kroczek, seria „Annales Cannonici. Monographiae”, Kraków 2014.

Walencik D., Konkordat a sfera finansowo-majątkowa Kościoła Katolickiego w Polsce [w:] Konkordat Polski, red. P. Borecki, C. Janik, M. Winiarczyk-Kossakowska, Warszawa 1993.

Zawiślak M., Zmiana systemu finansowania Kościoła Katolickiego w świetle Konstytucji RP i Konkordatu [w:] Układowe formy regulacji stosunków między państwem a związkami wyznaniowymi (art. 25 ust. 4-5 Konstytucji RP), red. P. Stanisz, M. Ordon, Lublin 2013.

Zieliński T.J., Implikacje art. 25 ust. 5 Konstytucji RP dla procedury parlamentarnej [w:] Układowe formy regulacji stosunków między państwem a związkami wyznaniowymi (art. 25 ust. 4-5 Konstytucji RP), red. P. Stanisz, M. Ordon, Lublin 2013. 